ment of Cushing's syndrome. Review of published work suggests that such cases are rare. In one case sarcoidosis presented after adrenalectomy in a patient with Carney's syndrome (primary adrenocortical nodular dysplasia, cardiac myxomas, and spotty pigmentation). ${ }^{2}$ A case of inflammatory polyarthritis has been reported after surgery, the articular symptoms responding to hydrocortisone replacement. ${ }^{3}$
1 Scadding JG. Sarcoidosis. London: Eyre and Spottiswood, 1967:307-13

2 Akama H, Tanaka H, Yamada H, Oshima H, Ichikawa Y, Yoshida T, et al. Cushing's syndrome due to primary adrenocortical nodular dysplasia, cardiac Curomes and spoty pigmentation complicated by sarcoidosis. Intemal Medicine 1992;31:1329-34.

3 Raccah D, Zeltoun C, Lafforgue P, Lassmann-Vague V, Mallet B, Vialettes B, et al. Inflammatory rheumatism flare-up after surgical treatment of Cushing's disease. Rev Med Interne 1992;13:302-4.

(Accepted 16 December 1994)

\section{Centers for Disease}

Control and Prevention, Mailstop E-44, Atlanta, GA 30333, USA

Robert M Brackbill, epidemiologist Paul Z Siegel, medical epidemiologist Susan P Ackermann, statistician

Correspondence to: Dr Brackbill.

$B M \mathcal{F} 1995 ; 310: 568$

\section{Self reported hypertension among unemployed people in the United States}

\author{
Robert M Brackbill, Paul Z Siegel, \\ Susan P Ackermann
}

Higher death rates from cardiovascular diseases have been reported among unemployed people in several countries after age, socioeconomic status, and marital status have been controlled for. Other studies have found that blood pressure and serum cholesterol concentration rise before and after loss of a job. Moreover, unemployed people consult doctors about cardiovascular conditions including hypertension, more often than do employed people. ${ }^{1}$ We used data from a cross sectional survey of American adults to estimate the risk of hypertension among unemployed people after controlling for other risk factors.

\section{Subjects, methods, and results}

In 1992, 48 states and the District of Columbia participated in the behavioural risk factor surveillance system, which entailed interviewing people by telephone who had been contacted by dialling random numbers. A total of 96213 people were interviewed. The median percentage of complete interviews for all the states was $82 \%$. The percentages of respondents who had had their blood pressure checked in the past year were similar by demographic group. People who had not had their blood pressure checked in the past year were excluded. This study included people aged 30-59 who were available for work outside the home $(n=36957)$. Data for each state were weighted demographically and by selection probability.

Subjects were categorised as having hypertension if they had been told more than once by a health care professional that they had high blood pressure. Employed people either had an employer or were self employed $(n=34120)$. Unemployed respondents had been out of work for less than a year $(n=1314)$ or a year or more $(n=1523)$. Rates of unemployment estimated by the behavioural risk factor surveillance system were significantly correlated by state with unemployment rates obtained from the United States Bureau of Labor Statistics.

We computed prevalence odds ratios by logistic regression ${ }^{2}$ to estimate the relative risk of hypertension among unemployed people. These ratios were adjusted for age, body mass, racial or ethnic group, education, and alcohol consumption. The table shows the results. People who reported having been unemployed for a year or more had a higher estimated risk of hypertension than those who reported having been unemployed less than a year. Unemployed men with less than a high school education had the highest risk of hypertension (prevalence odds ratio $3 \cdot 1$ (95\% confidence interval 2.5 to $4 \cdot 6$ )), but men who had graduated from high school and been unemployed for a year or more still had an increased risk (table). Women who
Adjusted prevalence odds ratios (95\% confidence intervals) for self reported hypertension among unemployed Americans aged 30-59, by length of unemployment, education, and sex *

\begin{tabular}{|c|c|c|}
\hline \multirow[b]{2}{*}{ Education } & \multicolumn{2}{|c|}{ Unemployed } \\
\hline & $<1$ year & $\geqslant 1$ year \\
\hline Whole sample: & $1.3(1.0$ to 1.6$)$ & $1.7(1.4$ to $2 \cdot 1)$ \\
\hline $\begin{array}{l}\text { Men: } \\
\text { Did not graduate from high school }\end{array}$ & $3 \cdot 0(2 \cdot 2$ to $4 \cdot 1)$ & $3 \cdot 3(2 \cdot 1$ to $5 \cdot 2)$ \\
\hline $\begin{array}{l}\text { Graauated from nigh or technical } \\
\text { school } \\
\text { Educated beyond high or technical }\end{array}$ & $0.8(0.4$ to 1.6$)$ & $2.0(1.3$ to 3.2$)$ \\
\hline school & $1.1(0.6$ to 2.0$)$ & $1.5(0.7$ to 3.6$)$ \\
\hline $\begin{array}{l}\text { Total } \\
\text { Women: }\end{array}$ & $1.3(0.9$ to 1.8$)$ & $2.2(1.7$ to 2.9$)$ \\
\hline $\begin{array}{l}\text { Did not graduate from high school } \\
\text { Graduated from high or technical }\end{array}$ & $1.7(0.8$ to 3.3$)$ & $2.4(1.5$ to 3.9$)$ \\
\hline $\begin{array}{l}\text { school } \\
\text { Educated beyond high or technical }\end{array}$ & $1 \cdot 2(0 \cdot 7$ to $2 \cdot 1)$ & $1.3(0.9$ to $2 \cdot 1)$ \\
\hline school & $1.3(0 \cdot 8$ to $2 \cdot 2)$ & $0.8(0.5$ to 1.3$)$ \\
\hline Total & $1.3(0.9$ to 1.6$)$ & $1.7(1.4$ to $2 \cdot 1)$ \\
\hline
\end{tabular}

^Behavioural risk factor surveillance system, 1992.

had been unemployed for a year or more and had less than a high school education had an increased risk of hypertension (table). Age (prevalence odds ratio $\mathrm{e}^{0.06}$ ( $95 \%$ confidence interval $\mathrm{e}^{0.059}$ to $\left.\mathrm{e}^{0.062}\right)$ ), body mass $\left(\mathrm{e}^{0.13}\right.$ $\left(\mathrm{e}^{0.10}\right.$ to $\left.\left.\mathrm{e}^{0.14}\right)\right)$, being black $\left(\mathrm{e}^{0.42},\left(\mathrm{e}^{0.28}\right.\right.$ to $\left.\left.\mathrm{e}^{0.56}\right)\right)$, and alcohol consumption ( $\mathrm{e}^{0.09}$ per ounce $(28 \mathrm{~g})\left(\mathrm{e}^{0.05}\right.$ to $\left.\mathrm{e}^{0.13}\right)$ ) predicted self reported hypertension; sex did not.

\section{Comment}

The prevalence of self reported hypertension was increased among unemployed people in the United States, especially among men with less education. This is consistent with the association of lower education with a higher prevalence of hypertension ${ }^{3}$ and the fact that men are more adversely affected by unemployment than women. ${ }^{4}$

The recognised limitations of this study are that the subjects could have misclassified their hypertension and employment status and that we did not control for health selection bias - that is, unemployment because of poor health. Other studies have indicated that self reported hypertension is quite accurate and that people who lose their jobs involuntarily suffer adverse health consequences. To our knowledge, however, no other population based study has shown increased hypertension among unemployed people after other risk factors have been controlled for.

Stress with job loss and subsequent unemployment may result in adverse physical and mental health. Stressful life events, including unemployment, may precede heart disease. ${ }^{5}$ We recommend that unemployed people receive appropriate screening for and treatment of hypertension, especially those in poorer socioeconomic groups.

1 Smith R. Unemployment: here we go again. $B M f$ 1991;305:972.

2 Research Triangle Institute. Survey data analysis (SUDAAN). Version 5.30 Research Triangle Park. NC: Research Triangle Institute, 1989.

3 Franco LJ, Stern MP, Rosenthal M, Haffner SM, Hazuda HP, Comeaux PJ. Prevalence, detection, and control of hypertension in a bioethnic community: Prevalence, detection, and control of hypertension in a bioeth

4 Leeflang RLI, Klein-Hesselink DJ, Spruit IP. Health effects of unemployment. Leeflang RLI, Klein-Hesselink DJ, Spruit IP. Health

5 Theorell T, Lind E, Floderus B. The relationship of disturbing life changes and emotions to the early development of myocardial infarctions and other serious illness. Int $\mathcal{F}$ Epidemiol 1975; 4:281-93.

(Accepted 9 November 1994) 